\title{
Effect of Tempering Temperature and Applied Load on Wear Behavior of Carburized Mild Steel
}

\author{
Kalpana Sachan ${ }^{1,}$ Dr. Dushyant Singh ${ }^{2}$, Shristee Singh ${ }^{3}$ \\ ME II Year, Material Science And Engineering, Department Of Mechanical Engineering ,BUIT, Bhopal (M.P.)
}

\begin{abstract}
This work presents the effect on wear behavior of as received and carburized mild steel sample at different load like $75 \mathrm{~N}, 200 \mathrm{~N}$, and $375 \mathrm{~N}$ and at different tempering temperature like $200{ }^{\circ} \mathrm{C}, 250{ }^{\circ} \mathrm{C}$ and $300{ }^{\circ} \mathrm{C}$. The mild steel sample was carburized at $950{ }^{\circ} \mathrm{C}$. The heat treatment after carburization has been acknowledge that at some instant it improving the various properties of mild steel. The mechanical properties and wear behavior of mild steel samples carburized at temperature of $950{ }^{\circ} \mathrm{C}$ and tempered at different tempering temperature of $200{ }^{\circ} \mathrm{C}, 250{ }^{\circ} \mathrm{C}$ and $300{ }^{\circ} \mathrm{C}$ have been studied and it is observed that the sample with heat treatment improves the hardness, tensile strength and wear resistance of mild steel. For this experiment firstly the mild steel samples are carburized at temperature $950{ }^{\circ} \mathrm{C}$ than soaking for two hour and then it is tempered at different temperature range of $200{ }^{\circ} \mathrm{C}, 250{ }^{\circ} \mathrm{C}$ and $300{ }^{\circ} \mathrm{C}$ for half an hour. After this the carburized and tempered mild steel samples are subjected for different kind of test such as abrasive wear test at different load like $75 \mathrm{~N}, 200 \mathrm{~N}$ and $375 \mathrm{~N}$, Hardness test and Tensile test. The result of these experiment shows that the carburized and tempered process greatly improve the mechanical and wear properties like hardness, tensile strength and wear resistance and these properties increases with increase in tempering temperature. The aim of these experiments to examine the effects on mechanical and wear properties of the carburized and tempered at different temperature, mild steel samples.
\end{abstract}

Keywords :- Carburization, Heat treatment, Abrasive wear, Tensile test, Hardness test

\section{INTRODUCTION}

Steel is an alloy that consists mostly of iron and has a carbon content between $0.2 \%$ to $2.1 \%$ by weight, depending on the grade[1]. Carbon is the most common alloying material for iron, but various other alloying elements are used, such as manganese, chromium, vanadium, and tungsten. Carbon and other elements act as a hardening agent, preventing dislocations in the iron atom crystal lattice from sliding past one another. Varying the amount of alloying elements and the form of their presence in the steel (solute elements, precipitated phase) controls qualities such as the hardness, ductility, and tensile strength of the resulting steel.

\subsection{General Material Classifications:-}

There are thousands of materials available for use in engineering applications. Most materials fall into one of three classes that are based on the atomic bonding forces of a particular material. These three classifications are metallic, ceramic and polymeric. Additionally, different materials can be combined to create a composite material. Within each of these classifications, materials are often further organized into groups based on their chemical composition or certain physical or mechanical properties. Composite materials are often grouped by the types of materials combined or the way the materials are arranged together. Below is a list of some of the commonly classification of materials within these four general groups of materials.[1]

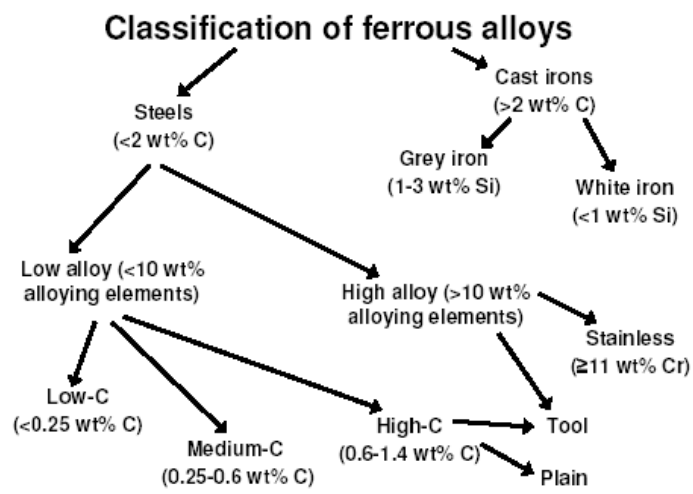

Figure: 1 The general classification of ferrous alloys 


\section{SPECIMEN FOR ABRASIVE WEAR TEST}

The abrasive wear is determined for the As received (AR) specimen which was carburized at $950^{\circ} \mathrm{C}$. A standard specimen of dimensions $(75 \mathrm{~mm} \times 25 \mathrm{~mm} \times 7 \mathrm{~mm}$ ) of As received (AR) specimen is prepared for the same purpose.

\section{CARBURIZATION OF MILD STEEL SAMPLES}

The sample were heat treated using electric furnaces. The different test specimen samples made up of mild steel for mechanical and wear properties testing were subjected for solid carburization treatment[4]. In this process the mild steel samples were placed on the thick bed of carburizer kept in a stainless steel container and fully covered from all sides, the top of the container was covered with a steel plate. The container was then introduced into the electric furnace and then maintained at the carburization temperatures of $950^{\circ} \mathrm{C}$ with the soak time of 2 hours by this way the mild steel samples gets carburized and then they were quenched in water i.e. the hardening was effected immediately after carburization.

\section{TEMPERING OF CARBURIZED MILD STEEL SAMPLES}

After the carburization process, the steel is often harder than needed and is too brittle for most practical uses. Also, severe internal stresses are set up during the rapid cooling from the hardening temperature[5]. To relieve the internal stresses and reduce brittleness, we should temper the steel after it is hardened. So in this tempering process the carburized steel samples were heated at the different temperature $200^{\circ} \mathrm{C}, 250^{\circ} \mathrm{Cand}$ $300^{\circ} \mathrm{C}$ for duration of 2 hours and then cooling it usually in the still air[6].

\section{ABRASIVE WEAR TESTS}

Weight loss of the specimen was measured after each 138 meters travel of the wheel. Specimen after abrasive wear test are shown in Figure 2. The wear rate was calculated from the weight loss measurement and expressed in the terms of volume loss per unit sliding distance i.e. in $\mathrm{m}^{3} / \mathrm{m}$. [2][3]

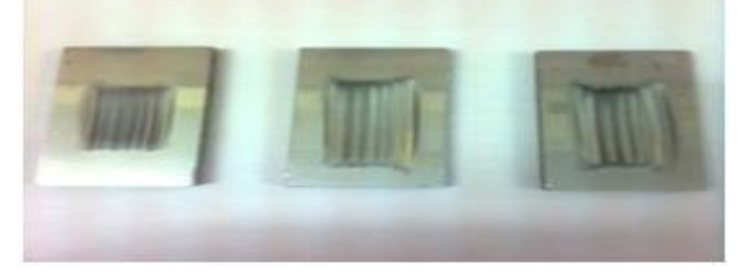

Figure: 2 Specimens after wear test (AR)

Wear rate $\left(\mathrm{W}_{\mathrm{r}}\right)$ for each set of experiment is calculated using the following formula:

$$
\mathrm{W}_{\mathrm{r}}=\left(\mathrm{W}_{\mathrm{i}}-\mathrm{W}_{\mathrm{f}}\right) /(\rho . \mathrm{D})
$$

Where, $\mathrm{W}_{\mathrm{i}}$ is the initial weight of specimen before the test has been started, $\mathrm{W}_{\mathrm{f}}$ is the final weight of specimen after the wear test has been completed, $\rho$ is the density of the test specimen material and $\mathrm{D}$ is the sliding distance.

During abrasive wear testing, the load was kept as $1 \mathrm{~kg}, 6 \mathrm{~kg}$ and $13 \mathrm{~kg}$. The mild steel samples of as received material and heat treated samples were tested. The specimens after wear test of as received and heat treated sample at Different temperature and load at $1 \mathrm{~kg}$ are shown in the figure 3 . Where first sample is the as received sample and the second sample is Heat

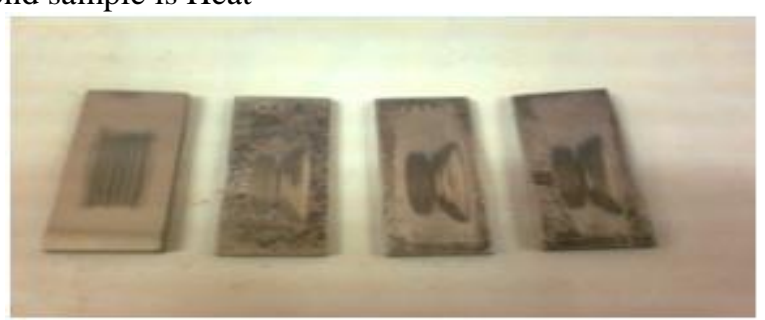

Figure: 3 Specimens after wear test of AR and HT at Different temperature at $1 \mathrm{~kg}$ load

treated at $200{ }^{\circ} \mathrm{C}$ and the third sample is Heat treated at $250^{\circ} \mathrm{C}$ and the last sample is Heat treated at $300^{\circ} \mathrm{C}$. The specimens after wear test of As received and heat treated sample at Different temperature and load at 6 $\mathrm{kg}$ are shown in the figure 4 . Where first sample is the As received sample and the second sample is Heat treated at $200{ }^{\circ} \mathrm{C}$ and the third sample is Heat treated at $250^{\circ} \mathrm{C}$ and the last sample is Heat treated at $300^{\circ} \mathrm{C}$. 


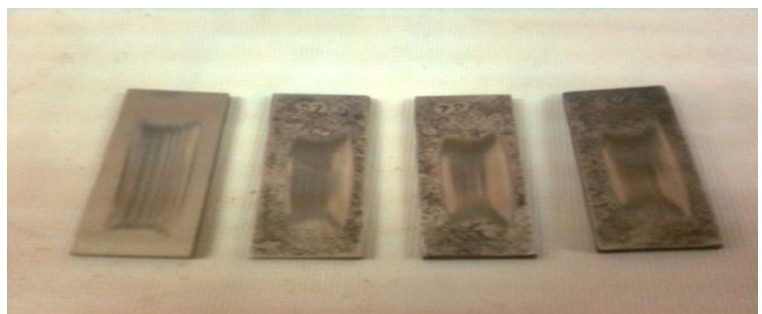

Figure :4 Specimens after wear test of AR and HT at Different temperature at $6 \mathrm{~kg}$ load

The specimens after wear test of As received and heat treated sample at Different temperature and load at $13 \mathrm{~kg}$ are shown in the figure 5. Where first sample is the As received sample and the second sample is Heat treated at $200{ }^{\circ} \mathrm{C}$ and the third sample is Heat treated at $250^{\circ} \mathrm{C}$ and the last sample is Heat treated at $300^{\circ} \mathrm{C}$.

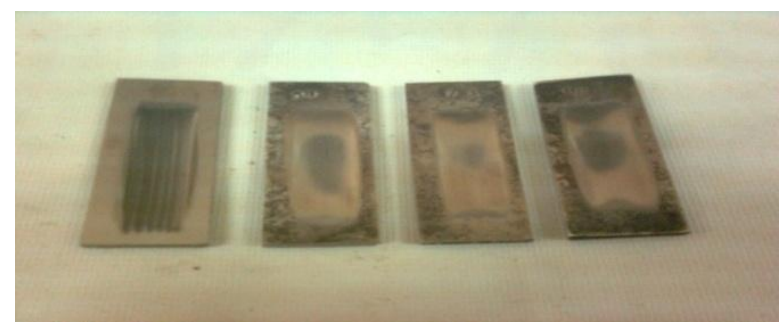

Figure :5 Specimens after wear test of AR and HT at Different temperature at $13 \mathrm{~kg}$ load

5.1 Effect of sliding distance on the wear behaviour of As received mild steel at different load's :-

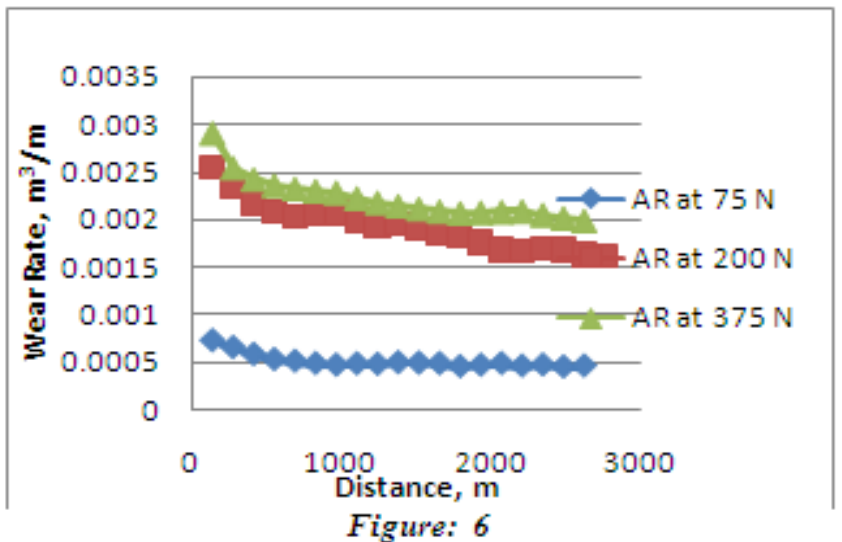

It is evident from the figure 6 that the wear rate is initially more and then decreases with increase in sliding distance and reach to a stable value at all load's.

5.2 Effect of sliding distance on the wear behaviour of carburised mild steel at load $75 \mathrm{~N}$ and different tempering temperature :-

The figure 7 indicates that

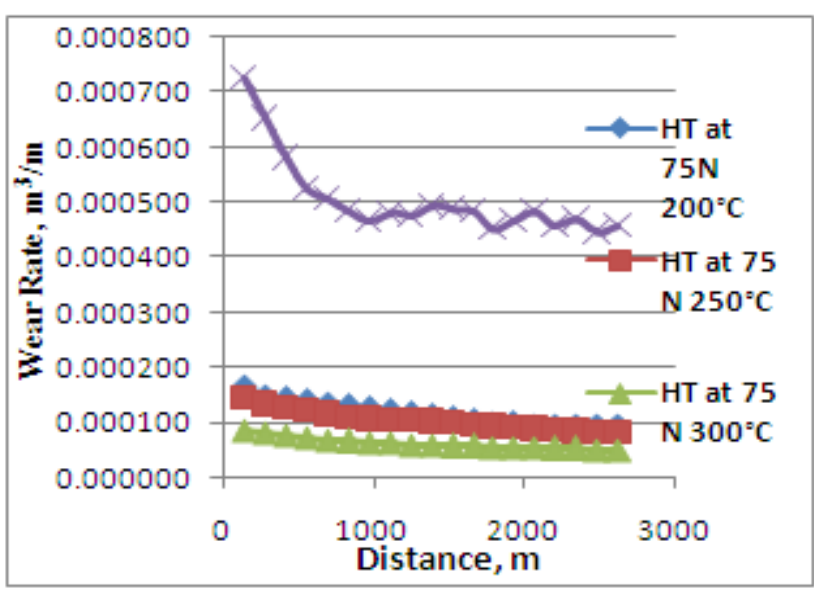

Figure : 7

www.iosrjen.org 
the carburised and tempered mild steel exhibit least wear rate at $75 \mathrm{~N}$ load. The As received steel sample gives higher wear rate as compared with carburised and tempered mild steel. From the figure 7 it is observed that at $300^{\circ} \mathrm{C}$ wear rate is less comparison to wear rate at $250^{\circ} \mathrm{C}$ and $200^{\circ} \mathrm{C}$. The specimen exhibits minimum wear rate when subjected to carburised and tempered because of highest hardness.

5.3 Effect of sliding distance on the wear behaviour of carburised mild steel at load $200 \mathrm{~N}$ and different tempering temperature :-

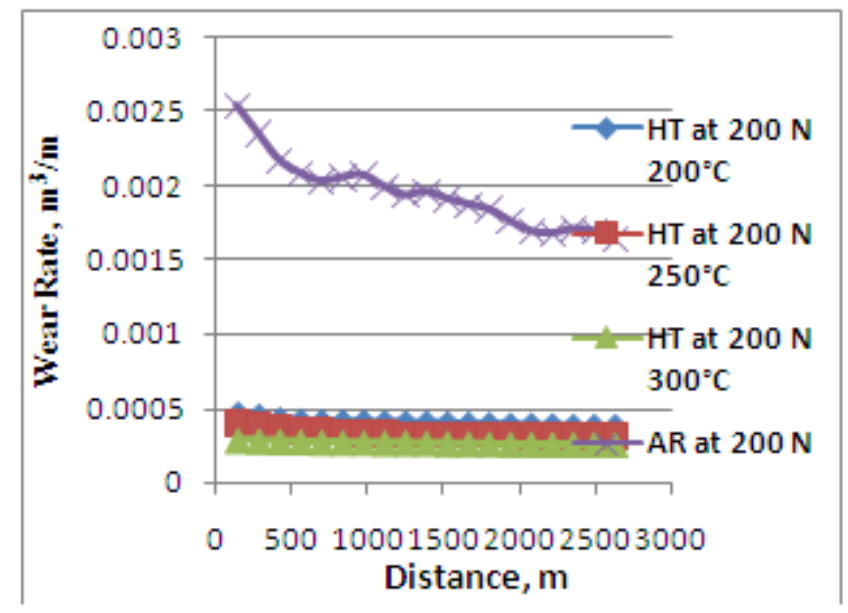

Figure : 8

The figure 8 indicates that the carburised and tempered mild steel exhibit less value of wear rate at $200 \mathrm{~N}$ load. The As received steel sample gives higher wear rate as compared with carburised and tempered mild steel. It is evident from the figure 8 that the wear rate reduces with sliding distance and finally approaches to a almost constant value. From the graph it is found that wear rate is decreasing with the increment of tempering temperature. It is also concluded from the fig 7 and fig 8 with the increment in the load value wear rate is also increasing.

5.4 Effect of sliding distance on the wear behaviour of carburised mild steel at load $375 \mathrm{~N}$ and different tempering temperature :-

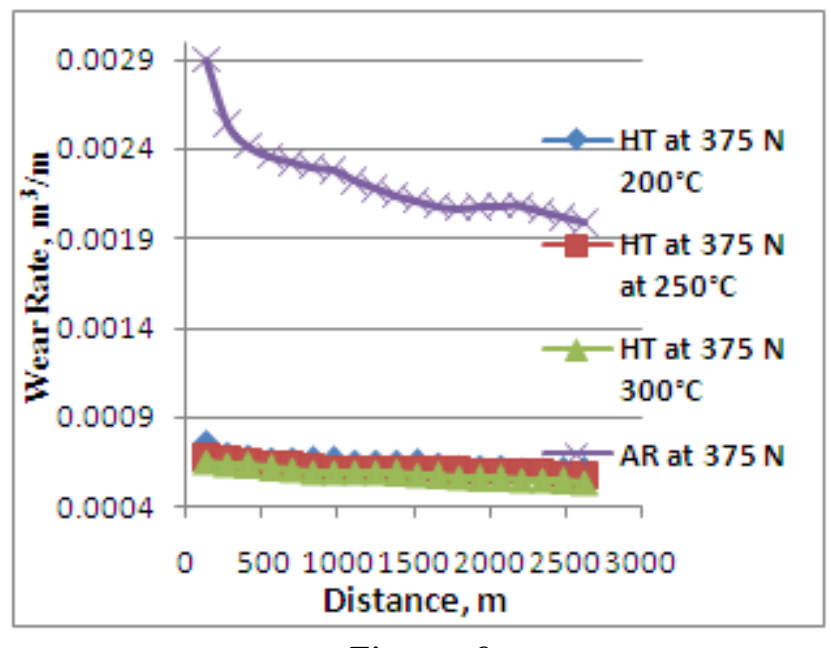

Figure : 9

The above figure 9 indicates that the carburised and tempered mild steel exhibit less value of wear rate at $375 \mathrm{~N}$ load as compared to As received mild steel sample. it is evident from the graph that the wear rate is decreasing with increment in the tempering temperature. It is also evident from the graph that, at $375 \mathrm{~N}$ load wear rate is more as compared to $200 \mathrm{~N}$ and $75 \mathrm{~N}$ load at same tampering scheme.

5.5 Effect of sliding distance on the wear behaviour of carburised mild steel at constant tempering temperature of $200^{\circ} \mathrm{C}$ at different load :- 


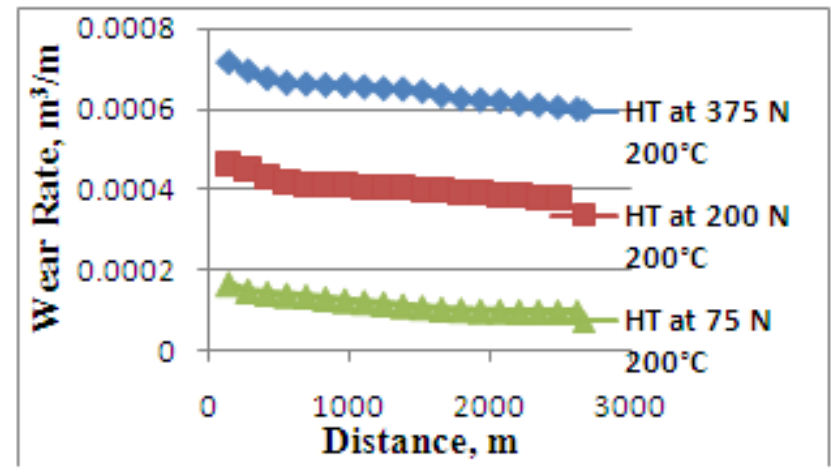

Figure : 10

It is evident from the figure 10 that the wear rate reduces with sliding distance and finally approaches to a stable value. It is also evident from the figure 10 that the wear rate is higher at $375 \mathrm{~N}$ load and then it is high at $200 \mathrm{~N}$ load and it is less at $75 \mathrm{~N}$ load at constant tempering temperature of $200^{\circ} \mathrm{C}$.

5.6 Effect of sliding distance on the wear behaviour of carburised mild steel at constant tempering temperature of $250^{\circ} \mathrm{C}$ at different load :-

It is evident from the figure 11 that the wear rate reduces with sliding distance and finally approaches to a

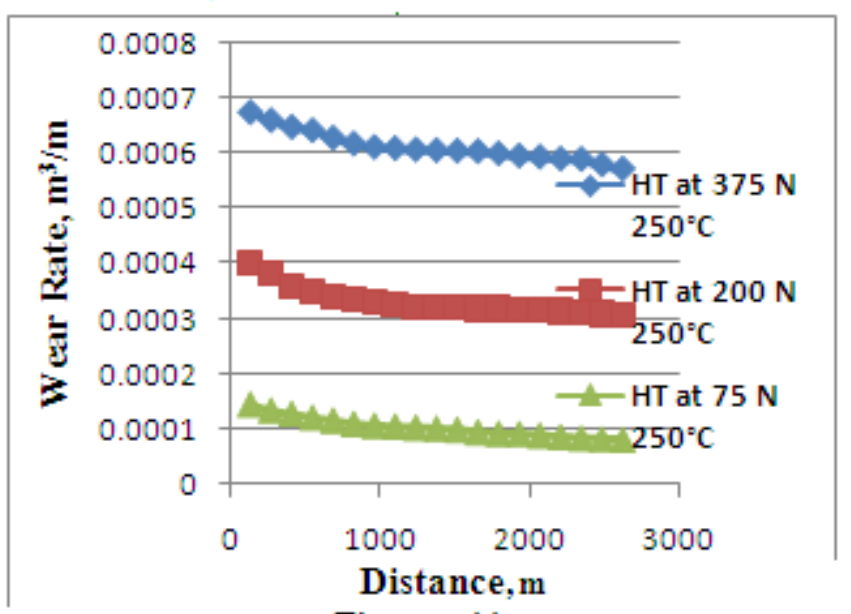

Figure : 11

stable value. It is also evident from the figure 11 that the wear rate is higher at $375 \mathrm{~N}$ load and then it is high at $200 \mathrm{~N}$ load and it is less at $75 \mathrm{~N}$ load at constant tempering temperature of $250^{\circ} \mathrm{C}$.

5.7 Effect of sliding distance on the wear behaviour of carburised mild steel at constant tempering temperature of $250^{\circ} \mathrm{C}$ at different load :-

It is evident from the figure 12 that the wear rate reduces with sliding distance and finally approaches to a stable value. It is

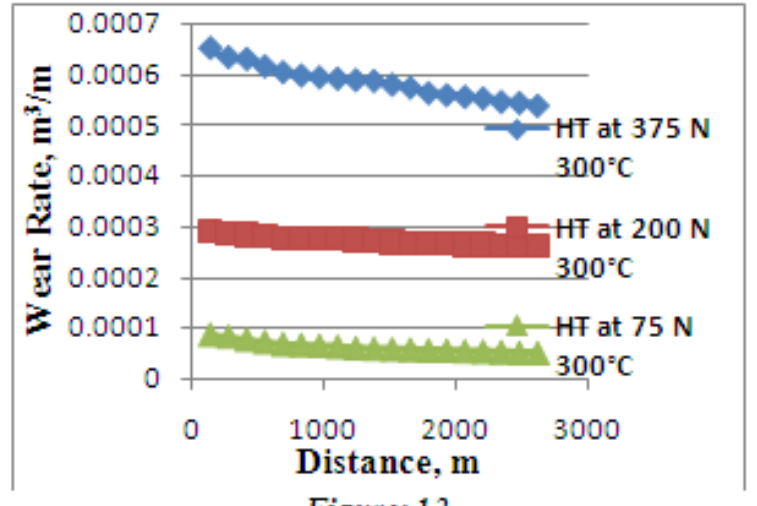

Figure: 12 
also evident that the wear rate is higher at $375 \mathrm{~N}$ load and then it is high at $200 \mathrm{~N}$ load and it is less at $75 \mathrm{~N}$ load at constant tempering temperature of $300^{\circ} \mathrm{C}$.

\subsection{Effect of Load on the wear behaviour of carburised mild steel samples at different tempering} temperature of $200^{\circ} \mathrm{C}, 250^{\circ} \mathrm{C}$ and $300^{\circ} \mathrm{C}$

It is evident from the figure 13 that the wear rate is increasing with the increment in load value. It's indicate that there is a almost uniform relation between wear rate versus applied load. It is also evident from the figure that, which sample was heat treated at $200{ }^{\circ} \mathrm{C}$ temperature showing more wear rate and which sample was

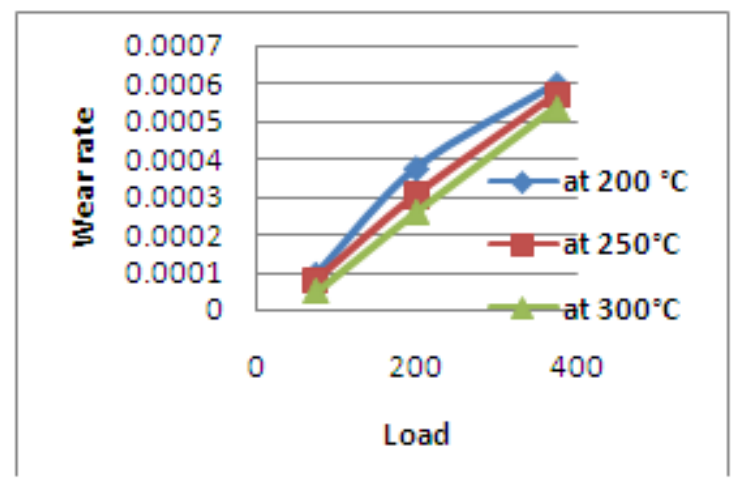

Figure : 13

heat treated at $300{ }^{\circ} \mathrm{C}$ temperature showing less value of wear rate.

\section{HARDNESS TEST}

Rockwell hardness testing is a general method for measuring the bulk hardness of metallic and polymer materials. Hardness testing is widely used for material evaluation due to its simplicity and low cost relative to direct measurement of many properties. In present experimental work Rockwell hardness was measured on carburized and tempered mild steel samples which are carburized under temperature $950{ }^{\circ} \mathrm{C}$. For each of the sample, test was conducted for 5 times and the average of all the samples was taken as the observed values in each case.

\section{TENSILE TEST}

The tensile strength is measured by tensile test which is carried out on Universal testing machine (UTM). This involves the preparation of a test specimen as shown in figure 14.

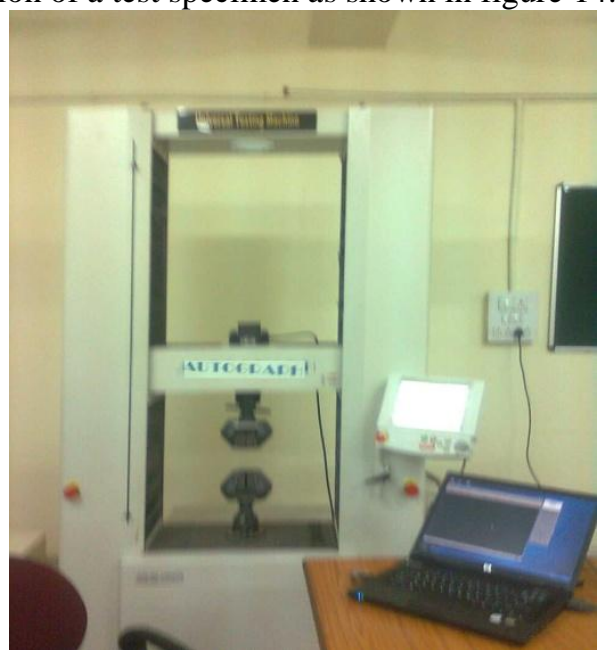

Figure 14: Universal testing machines (UTM) for tensile test

VIII. RESULTS

In this experiment The different kind of mild steel samples were carburized at $950^{\circ} \mathrm{C}$ and tempered under the different tempering temperature like $200^{\circ} \mathrm{C}, 250^{\circ} \mathrm{C}$ and $300^{\circ} \mathrm{C}$ and then tested for various kinds of test like abrasive wear test, tensile strength test and hardness test. The results of abrasive wear test for As received mild steel sample and the mild steel samples carburized at $950^{\circ} \mathrm{C}$ and tempered at $200^{\circ} \mathrm{C}, 250^{\circ} \mathrm{C}$ and $300^{\circ} \mathrm{C}$ for different load (i.e.75 N, $200 \mathrm{~N}$ and $375 \mathrm{~N}$ ) is recorded in Table 4.1, Table 4.2 and Table 4.3, the result of 
Rockwell hardness test at $150 \mathrm{~kg}$ load is recorded in Table 4.4. Similarly the result of tensile strength test is recorded in Table 4.5 .

8.1 Results of abrasive wear test: - The results of abrasive wear test of carburized mild steel samples tempered at different temperature of $200^{\circ} \mathrm{C}, 250^{\circ} \mathrm{C}$ and $300^{\circ} \mathrm{C}$ is shown in Table 4.1, Table 4.2 and Table 4.3. The weight loss as a function of hardness for these steels samples. the weight loss during abrasion of all these carburized steels decreases linearly with the increase of hardness and tempering temperature. This can be observed from the Table 4.1, Table 4.2 and Table 4.3. From the experimental results of abrasive wear test the following regularities can be found :

$>$ The abrasion wear test is conducted under three different loads of $75 \mathrm{~N}, 200 \mathrm{~N}$ and $375 \mathrm{~N}$ and it is obtained from the test that the weight loss during the abrasion is highest for the load of $375 \mathrm{~N}$ and the weight loss is lowest for the load of $75 \mathrm{~N}$. so it is concluded from the test that, as the load increases the weight loss during abrasion . this results is also shown in the Table 4.1, Table 4.2 and Table 4.3.

$>$ The wear rate is highest for un carburized mild steel sample and is lowest for the mild steel sample carburized at temperature of $950^{\circ} \mathrm{C}$ and heat treated at $200^{\circ} \mathrm{C}, 250^{\circ} \mathrm{C}$ and $300^{\circ} \mathrm{C}$ and this wear rate is gradually decreases with increase in tempering temperature, these results shown graphically in Figure 6 to figure 9 . This is due to the fact that the weight loss during abrasion is directly proportional to the wear rate.

$>$ The wear rate is also depend on load and the abrasion test results shows that the wear rate increases almost linear while increasing the applied load, so the wear rate is highest for the load of $375 \mathrm{~N}$ and it is lowest for the load of $75 \mathrm{~N}$. This comparison shown graphically in the Figure 10 to figure 13.

$>$ The wear resistance is highest for the mild steel carburized at the temperature of $950^{\circ} \mathrm{C}$ and tempered at $200^{\circ} \mathrm{C}, 250^{\circ} \mathrm{C}$ and $300^{\circ} \mathrm{C}$. it is lowest for the un carburized mild steel. For the case of only carburized mild steels the wear resistance is highest for the mild steel carburized at the temperature of $950^{\circ} \mathrm{C}$ and tempered at $300^{\circ} \mathrm{C}$ and it is lowest for mild steels carburized at temperature of $950^{\circ} \mathrm{C}$ and tempered at $200^{\circ} \mathrm{C}$. Hence the abrasion results explain that the wear resistance is directly proportional to the tempering temperature, as the tempering temperature increases the wear resistance increases. These results shown in the table 4.1 to table 4.3 .

$>$ The weight loss during abrasion is highest for As received mild steel and it is lowest for the mild steel carburized at temperature of $950^{\circ} \mathrm{C}$ and tempered at $200^{\circ} \mathrm{C}, 250^{\circ} \mathrm{C}$ and $300^{\circ} \mathrm{C}$.

$>$ The net results is that the mild steel carburized at temperature of $950^{\circ} \mathrm{C}$ and tempered at $300^{\circ} \mathrm{C}$ giving the best results, it having the highest wear resistance, lowest weight loss due to abrasion and lowest wear rate.

8.2 Mechanical properties results (Tensile strength and hardness test results):- The heat treatment and carburization of mild steels at different tempering temperature resulted in an increase in hardness, tensile strength and wear resistance and decreases the weight loss during abrasion. The tests results for different mechanical characteristics like hardness and tensile strength under the different tempering temperature of $200^{\circ} \mathrm{C}, 250^{\circ} \mathrm{C}$ and $300^{\circ} \mathrm{C}$ is shown in Table 4.4 and table 4.5 and result also summarized in the following points

: The tensile strength is varied between the ranges of $392 \mathrm{MPa}$ to $581 \mathrm{MPa}$ (Table 4.5) and it is highest for the mild steel carburized at temperature of $950^{\circ} \mathrm{C}$ and tempered at $300^{\circ} \mathrm{C}$ and lowest for the As received mild steel. From This results we can conclude that the tempering at $300^{\circ} \mathrm{C}$ improved the tensile strength of mild steels.

$>$ The hardness values varied between range of $28 \mathrm{Rc}$ to $46 \mathrm{Rc}$ and it is highest for the mild steel carburized at temperature of $950^{\circ} \mathrm{C}$ and tempered at $300^{\circ} \mathrm{C}$ and is lowest for the mild steels carburized at $950^{\circ} \mathrm{C}$ and tempered at $200^{\circ} \mathrm{C}$, so with increase of tempering temperature the hardness values increases. This is also shown in the table 4.4. It is very difficult to calculate the hardness values of as received mild steel in Rc because of its very less hardness values.

$>$ Finally the net results is that the mild steels carburized at $950^{\circ} \mathrm{C}$ and tempered at $300^{\circ} \mathrm{C}$ is giving the best results for the mechanical and wear properties like tensile strength, hardness and wear resistance .

$>$ The tensile strength is highest for the mild steels tempered at the temperature $300^{\circ} \mathrm{C}$ and is lowest for the mild steels tempered at temperature $200^{\circ} \mathrm{C}$, which leads to the conclusion that with the increase in the tempering temperature, the tensile strength of tempered mild steels increases.

\section{CONCLUSIONS}

From this investigation the following conclusion can be made :

$>$ It is concluded from the experiment that the mechanical and wear properties of mild steels were strongly influenced by the carburization and tempering at different temperature. 
$>$ The heat treatment improved the hardness, wear resistance and tensile strength of mild steels.

$>$ The weight loss due abrasion and wear rate increases with the increase in the applied load.

The hardness, wear resistance and tensile strength increases with increase in the tempering temperature of carburized mild steel sample.

$>$ Weight loss due to abrasion and wear rate decreases with increase in the tempering temperature of carburized mild steel sample.

\section{REFERENCE}

1) Foundation of Materials Science and Engineering, $4^{\text {th }}$ ed, Mc. Graw hill; page no. 386 to 387 by Smith W. F and Hashemi j

2) Singh D., Mondal D.P. ,Sethi V.K. , and Sexena A. C. (2008) Advantage of shot peening on abrasive wear resistance of agricultural grade steel. Agricultural Engineering Today Vol. 33(3) pp14-19.

3) Mondal D.P. , singh D. , Kumar N. Ahmed S. and Sethi V.K. (2009) Effect of shot peening on abrasive wear behavior of medium carbon steel. Indian journal of Tribology vol 4 No. 1 pp 14-24.

4) Luo Q., Xie J. and Song Y. Effects of microstructure on the abrasive wear behavior of spheroidal cast iron, Wear, 184 ( 1995 ) : pp. 133 - 137.

5) Celik O. High temperature abrasive wear behavior of an as - cast ductile iron, wear, 258 ( 2005 ) : pp $189-193$.

6) Singh D., Mondal D.P. ,Sethi V.K. , and Modi O.P. (2010) Low stress abrasive wear response of boron steel under three body abrasion effect of heat treatment and peening intensity. Indian journal of Engineering and Material science vol. 17 pp. 208-218.

Table 4.1: Result of abrasive wear test for carburized mild steel, at load $75 \mathrm{~N}$

\begin{tabular}{|c|c|c|c|c|c|c|}
\hline \multicolumn{2}{|c|}{$\begin{array}{c}\text { Carburization } \\
\text { Data }\end{array}$} & \multicolumn{2}{|c|}{$\begin{array}{c}\text { Tempering } \\
\text { Data }\end{array}$} & \multirow{2}{*}{$\begin{array}{l}\text { Weight } \\
\text { loss ,g }\end{array}$} & \multirow{2}{*}{$\begin{array}{l}\text { Wear rate } \\
\mathrm{m}^{3 /} \mathrm{m} \times 10^{-5}\end{array}$} & \multirow{2}{*}{$\begin{array}{c}\text { Wear } \\
\text { resistance } \\
\mathbf{m} / \mathbf{m}^{3} \times 10^{3}\end{array}$} \\
\hline $\begin{array}{c}\text { Temperature } \\
\left({ }^{\circ} \mathrm{C}\right)\end{array}$ & $\begin{array}{l}\text { Soak } \\
\text { Time } \\
\text { (Hrs) }\end{array}$ & $\begin{array}{c}\text { Temperature } \\
\left({ }^{\circ} \mathrm{C}\right)\end{array}$ & $\begin{array}{l}\text { Soak } \\
\text { Time } \\
\text { (Hrs) }\end{array}$ & & & \\
\hline $\begin{array}{c}\text { As received } \\
\text { sample } \\
\end{array}$ & & & & 1.2 & 51.2 & 1.95 \\
\hline $950^{\circ} \mathrm{C}$ & 2 & $200^{\circ} \mathrm{C}$ & 0.5 & 0.802 & 40.4 & 2.476 \\
\hline $950^{\circ} \mathrm{C}$ & 2 & $250^{\circ} \mathrm{C}$ & 0.5 & 0.684 & 33.8 & 2.963 \\
\hline $950^{\circ} \mathrm{C}$ & 2 & $300^{\circ} \mathrm{C}$ & 0.5 & 0.132 & 7.8 & 12.89 \\
\hline
\end{tabular}

Table 4.2: Result of abrasive wear test for carburized mild steel, at load $200 \mathrm{~N}$

\begin{tabular}{|c|c|c|c|c|c|c|}
\hline \multicolumn{2}{|c|}{$\begin{array}{c}\text { Carburization } \\
\text { Data }\end{array}$} & \multicolumn{2}{|c|}{$\begin{array}{c}\text { Tempering } \\
\text { Data }\end{array}$} & \multirow{2}{*}{$\begin{array}{l}\text { Weight } \\
\text { loss ,g }\end{array}$} & \multirow{2}{*}{$\begin{array}{l}\text { Wear rate } \\
\mathrm{m}^{3 /} \mathrm{m} \times 10^{-5}\end{array}$} & \multirow{2}{*}{$\begin{array}{c}\text { Wear } \\
\text { resistance } \\
\mathrm{m} / \mathrm{m}^{3} \times 10^{3}\end{array}$} \\
\hline $\begin{array}{c}\text { Temperature } \\
\left({ }^{\circ} \mathbf{C}\right)\end{array}$ & $\begin{array}{l}\text { Soak } \\
\text { Time } \\
\text { (Hrs) }\end{array}$ & $\begin{array}{c}\text { Temperature } \\
\left({ }^{\circ} \mathbf{C}\right)\end{array}$ & $\begin{array}{l}\text { Soak } \\
\text { Time } \\
\text { (Hrs) }\end{array}$ & & & \\
\hline $\begin{array}{l}\text { As received } \\
\text { sample }\end{array}$ & & & & 4.5 & 219.4 & 0.45 \\
\hline $950^{\circ} \mathrm{C}$ & 2 & $200^{\circ} \mathrm{C}$ & 0.5 & 1.41 & 69.1 & 1.45 \\
\hline $950^{\circ} \mathrm{C}$ & 2 & $250^{\circ} \mathrm{C}$ & 0.5 & 0.986 & 52.3 & 1.91 \\
\hline $950^{\circ} \mathrm{C}$ & 2 & $300^{\circ} \mathrm{C}$ & 0.5 & 0.212 & 11.2 & 8.92 \\
\hline
\end{tabular}


Effect of Tempering Temperature and Applied Load on Wear Behavior of Carburized Mild Steel

Table 4.3: Result of abrasive wear test for carburized mild steel, at load $375 \mathrm{~N}$

\begin{tabular}{|c|c|c|c|c|c|c|}
\hline \multicolumn{2}{|c|}{$\begin{array}{c}\text { Carburization } \\
\text { Data }\end{array}$} & \multicolumn{2}{|c|}{$\begin{array}{l}\text { Tempering } \\
\text { Data }\end{array}$} & \multirow{2}{*}{$\begin{array}{l}\text { Weight } \\
\text { loss, g }\end{array}$} & \multirow{2}{*}{$\begin{array}{l}\text { Wear rate } \\
\mathbf{m}^{3 /} \mathbf{m} \times 10^{-5}\end{array}$} & \multirow{2}{*}{$\begin{array}{c}\text { Wear } \\
\text { resistance } \\
\mathbf{m} / \mathbf{m}^{3} \times 10^{3}\end{array}$} \\
\hline $\begin{array}{l}\text { Temperature } \\
\left({ }^{\circ} \mathrm{C}\right)\end{array}$ & $\begin{array}{l}\text { Soak } \\
\text { Time } \\
\text { (Hrs) }\end{array}$ & $\begin{array}{l}\text { Temperature } \\
\left({ }^{\circ} \mathrm{C}\right)\end{array}$ & $\begin{array}{l}\text { Soak } \\
\text { Time } \\
\text { (Hrs) }\end{array}$ & & & \\
\hline $\begin{array}{l}\text { As received } \\
\text { sample }\end{array}$ & & & & 5.2 & 293.2 & 0.34 \\
\hline $950^{\circ} \mathrm{C}$ & 2 & $200^{\circ} \mathrm{C}$ & 0.5 & 1.735 & 95.8 & 1.04 \\
\hline $950^{\circ} \mathrm{C}$ & 2 & $250^{\circ} \mathrm{C}$ & 0.5 & 1.498 & 82.7 & 1.21 \\
\hline $950^{\circ} \mathrm{C}$ & 2 & $300^{\circ} \mathrm{C}$ & 0.5 & 0.248 & 13.4 & 7.47 \\
\hline
\end{tabular}

Table 4.4: Rockwell hardness of carburized mild steel at load $150 \mathrm{Kg}$

\begin{tabular}{|c|c|c|c|c|}
\hline \multicolumn{2}{|c|}{ Carburization condition } & \multicolumn{2}{|c|}{ Temperature condition } & \multirow{2}{*}{$\begin{array}{l}\text { Hardness } \\
\text { (Rc) }\end{array}$} \\
\hline $\begin{array}{c}\text { Temperature } \\
\left({ }^{\circ} \mathrm{C}\right)\end{array}$ & $\begin{array}{c}\text { Soak } \\
\text { Time (Hrs) }\end{array}$ & $\begin{array}{c}\text { Temperature } \\
\left({ }^{\circ} \mathrm{C}\right)\end{array}$ & $\begin{array}{c}\text { Soak } \\
\text { Time (Hrs) }\end{array}$ & \\
\hline $950^{\circ} \mathrm{C}$ & 2 & $200^{\circ} \mathrm{C}$ & 0.5 & 28 \\
\hline $950^{\circ} \mathrm{C}$ & 2 & $250^{\circ} \mathrm{C}$ & 0.5 & 30 \\
\hline $950^{\circ} \mathrm{C}$ & 2 & $300^{\circ} \mathrm{C}$ & 0.5 & 46 \\
\hline
\end{tabular}

Table 4.5: Tensile strength of carburized mild steel tempered at different temperature

\begin{tabular}{|c|c|c|c|c|}
\hline \multicolumn{2}{|c|}{ Carburization condition } & \multicolumn{2}{c|}{ Temperature condition } & \multirow{2}{*}{$\begin{array}{c}\text { Tensile strength } \\
\text { (mpa) }\end{array}$} \\
\cline { 1 - 3 } $\begin{array}{c}\text { Temperature } \\
\left({ }^{\circ} \mathrm{C}\right)\end{array}$ & $\begin{array}{c}\text { Soak } \\
\text { Time }(\mathrm{Hrs})\end{array}$ & $\begin{array}{c}\text { Temperature } \\
\left({ }^{\circ} \mathrm{C}\right)\end{array}$ & $\begin{array}{c}\text { Soak } \\
\text { Time }(\mathrm{Hrs})\end{array}$ & \multirow{2}{*}{392} \\
\hline $950^{\circ} \mathrm{C}$ & 2 & $200^{\circ} \mathrm{C}$ & 0.5 & 469 \\
\hline $950^{\circ} \mathrm{C}$ & 2 & $250^{\circ} \mathrm{C}$ & 0.5 & 581 \\
\hline $950^{\circ} \mathrm{C}$ & 2 & $300^{\circ} \mathrm{C}$ & 0.5 & 58 \\
\hline
\end{tabular}

